Article

\title{
The Share Price and Investment: Current Footprints for Future Oil and Gas Industry Performance
}

\author{
Ionel Jianu *(1) and Iulia Jianu \\ Department of Accounting and Audit, The Bucharest University of Economic Studies, Romana Square, No. 6, \\ 010374 Bucharest, Romania; jianu.iulia@cig.ase.ro \\ * Correspondence: ionel.jianu@cig.ase.ro; Tel.: +40-724-508-501
}

Received: 1 January 2018; Accepted: 13 February 2018; Published: 19 February 2018

\begin{abstract}
The share price has become a very important indicator for shareholders, banks, and financial institutions evaluating the performance of companies. The oil and gas industry seems to be in a difficult era of development, due to the market prices for its products. Moreover, climate change and renewable energies are barriers for fossil energy. This state of affairs, and the fact that oil and gas shares are considered one of the most solid and reliable shares on the London Stock Exchange (LSE), have drawn our attention. International institutions encourage the investment in the oil and gas economic sector. This study investigates how investments of oil and gas companies in long-term assets influence the share price. Using the Ohlson share price model for a sample of 51 listed companies on the LSE proves that investments in long-term assets influence the share price in the case of companies which record losses. Investments in long-term assets are responsible for the attractiveness of the oil and gas company shares.
\end{abstract}

Keywords: energy market; oil and gas industry; investments; share price; performance

\section{Introduction}

Nowadays, energy markets are facing a set of new challenges and risks [1]. There is an increasing pressure to move away from fossil energy. The new seems to replace the old and, practically, renewable energies are a solution to the classical ones [2]. Today, the topic of the oil and gas business is being discussed much more than in the past among researchers, practitioners, and policy-makers due to the importance of these energy resources for human activities, especially for their effect on climate change [3]. At the international level, more oil and gas companies have survived with poor demand and low prices [4]. Lately oil and gas prices have gone down, which could be a restriction to invest in the field. These moments are very important ones for the future of the company and also for the relations with its stakeholders. Stakeholder theory states that company decisions suppose a trade-off between the delivery of shareholder value and the benefit to other shareholders [5]. Additionally, the energy market is characterized by interactions among operators, states, and international bodies. In this context, managers must be able to create their own model of investment analysis, based on decisions related to the (re)development [6].

The development of modern society has been fuelled by the use of conventional oil and gas energy [7]. The companies must compete among themselves in different conditions. The market structure is important for business success. A company operates in a more cost-efficient manner in a tightly-regulated monopoly structure than it would do in a free market composed of multiple competitors [8]. Despite the care of the International Energy Agency for investment in the condition of market uncertainties and altered government spending priorities [9], there have been many investments in the following years which led to the break of the state monopoly over this business and to the development of the free oil and gas market. The liberalization of the gas and oil energy sector in some 
parts of the world is the starting point for the investments in this sector, through the appearance of the large and smaller energy companies [10]. We believe that these, together with investments in long-term assets, could be the key to future sustainable development, although, at this moment, the whole oil and gas industry is affected by low financial results, by low consuming demand, and by low prices of its products. The companies, through investments in long-term assets, provoke the appetite of investors to be part of their development process. The major investments in long-term assets could be seen as a way to achieve profit over the coming years. By using the share price model, this research demonstrated a very powerful relation between capital expenditure as a measure of investments in long-term assets and share price in the case of companies which record losses. Investments in long-term assets are responsible for filling the information gap created by the companies' losses and are also responsible for maintaining the attraction of oil and gas shares. We apply our analysis on the panel data, because these have several advantages over cross-sectional or time-series data, such as more accurate inference of model parameters, greater capacity for capturing the complexity of company behavior, and simplifying computation and statistical inference. Choosing to test our hypotheses when the oil and gas prices decreased (2014-2016 period) [11] and finding losses for companies, the positive correlation between share price and investments in long-term assets, through this research, the confidence of investors in the potential of development of oil and gas companies was determined.

The rest of this paper is organized as follows: Section 2 covers the research methodology, Section 3 presents the results and discussions, and Section 4 reports the conclusions.

\section{Research Methodology}

\subsection{Research Hypotheses}

The finance literature considers the impact of capital markets on the company's financial performance and the distribution of resources among different stakeholders [12]. In an efficient market, where information is quickly evaluated and reflected in the market prices, companies use many possibilities to finance their operations, among which include the issuing of shares. The share price determines the company's value and puts pressure on the company's management to create value for shareholders [13]. A company's share price is affected by the company-specific (idiosyncratic) and general market (systematic) information [14]. Market values capture financial and nonfinancial information that affect the company's value [15]. The companies' desires are to reach performance, to be in the top of industry and to be able to meet all stakeholders' needs. The company's financial performance could be decomposed into three-group classification: market-based, accounting-based and perceptual company financial performance measures [16]. Market-based measure shows the link between the company's financial performance and share price appreciation and reflects the statement that shareholders are primary stakeholders group [17].

Share price is a very important indicator for the investment world, being the tool of investors' control over the business or the tool of their fortune. In the literature, there are research studies which demonstrate the link between crude oil prices and oil company share price [18], between crude oil return volatility and oil and gas producer equity returns [19], and between share price and variation in crude oil prices [20]. Stakeholders need to understand the oil and gas industry in its economics and financial opportunities. In fact, the companies issue shares to raise their capital and investors buy their shares because they think that in the future the companies will be successful.

Investors see in investments in long-term assets the tool of bright future, the germs of the companies' performance, the way to improve their share performance. In this context the following hypotheses were tested in this paper:

Hypothesis 1. Investments in long-term assets have a positive effect on share price for the profit companies.

Hypothesis 2. Investments in long-term assets have a positive effect on share price for the loss companies. 


\subsection{Valuation Model}

In order to test how investments in long-term assets made by companies influence the share price, we used in our study the share price model of Ohlson (1995) [21]. This model reflects the market value of the company as a linear function of the book value of equity and earnings. The equity represents the residual interest in the company's assets after deduction of all its liabilities. Earnings reflect the net income of the company reported in the income statement. We chose to use the Ohlson price model for two reasons: firstly, because it is considered the best stock valuation model on financial markets [22] and, secondly, because it includes the book value of equity that could cross-sectionally proxy for net assets value and has the potential to reduce the correlated omitted variables problem [23]. This model was used in many studies as Collins et al. (1997) [24], Bao and Chow (1999) [25], Jianu et al. $(2017,2014)[26,27]$ in order to analyze the value relevance of financial information.

We extend the share price model adding one new independent variable, capital expenditure, which reflects the investments made by companies in long-term assets.

2.2.1. Ordinary Least Squares (OLS) Model

$$
\operatorname{PRICE}_{t, i}=\beta_{0}+\beta_{1} \text { EQUITY }_{t, i}+\beta_{2} \text { EPS }_{t, i}+\beta_{3} C E_{t, i}+\varepsilon_{t, i}
$$

where:

- $\quad$ PRICE $E_{t, i}$-share price for the year $t$ of the company $i$;

- EQUITY $_{t, i}$-book value of equity per share for the year $t$ of the company $i$;

- $E P S_{t, i} \quad$-annual earnings per share for the year $t$ of the company $i$; and

- $C E_{t, i}$-capital expenditure per share for the year $t$ of the company $i$.

To eliminate the heteroscedasticity of data, we divided the book value of equity by the common shares outstanding and the earnings and capital expenditure by the basic weighted average shares. Because in the sample there are time series data comprising the financial information for three years, we proceeded with two tests of heteroscedasticity: White's test and the modified Breusch-Pagan test, both tests proving the presence of the heteroscedasticity. In order to eliminate the heteroscedasticity, we transformed our data using a logarithm for all variables in the case of profit companies and a logarithm only for the dependent variable in the case of loss companies due to negative value of earnings.

Since, in a data panel with financial information, heterogeneity is expected between different companies, and because the OLS regression does not take into consideration the individual differences between companies, the OLS regression results could be biased and inconsistent. This will be solved by using a company fixed effects model that controls for the effects of time-invariant variables with time-invariant effects. Furthermore, the company fixed effects model is a way to control for omitted variable bias when these omitted variables are correlated with the explanatory variables in the model. In order to construct the company fixed effects model, the error is decomposed into an individual specific effect and a remainder error:

$$
\varepsilon_{t, i}=\mu_{i}+v_{t, i}
$$

where:

- $\quad \mu_{i}$-individual specific effect of all other variables that affect share price cross-sectionally, but do not vary over time; and

- $\quad v_{t, i}$-the remainder disturbance error that varies over time and companies.

Combining Equations (1) and (2) results in the equation for the company fixed effect model. Applying the transformation within, we subtract the time-means from each company to obtain a regression containing demeaned variables. 


\subsubsection{Company Fixed Effects Model}

$$
\left(\text { PRICE }_{t, i}-\overline{\operatorname{PRICE}}_{i}\right)=\beta_{1}\left(E_{\mathrm{QUUITY}},-\overline{\mathrm{EQUITY}}_{i, i}\right)+\beta_{2}\left(E P S_{t, i}-\overline{\mathrm{EPS}}_{i}\right)+\beta_{3}\left(C E_{t, i}-\overline{C E}_{i}\right)-\left(\mu_{t, i}-\bar{\mu}_{i}\right)
$$

Due to time variation, we have to test the model for time fixed effects. This is recommended to be used when the average value of the share price changes over time, but not among companies. In order to construct the time fixed effects model, the error is decomposed into a time specific effect and a remainder error:

$$
\varepsilon_{t, i}=\lambda_{t}+v_{t, i}
$$

where:

- $\lambda_{t}$-time specific effect of all other variables that affect share price in time but are constant between companies; and

- $v_{t, i}$-the remainder disturbance error that varies over time and companies.

Using the Equations (1) and (4) together, and applying the transformation within, we subtract the companies-means from each period of time and obtain a regression containing demeaned variables.

\subsubsection{Time Fixed Effects Model}

$$
\left(\text { PRICE }_{t, i}-\overline{P R I C E}_{t}\right)=\beta_{1}\left(E Q U I T Y_{t, i}-\overline{E Q U I T Y}_{t}\right)+\beta_{2}\left(E P S_{t, i}-\overline{E P S}_{t}\right)+\beta_{3}\left(C E_{t, i}-\overline{C E}_{t)}-\left(\lambda_{t, i}-\bar{\lambda}_{t}\right)\right.
$$

Since the impact of time-varying factors could not be controlled by the company fixed effects model and the time fixed effects model does not eliminate the omitted variables that vary between companies, we could mix the two models, obtaining the two-way error component model which combines the unobserved company effects with the unobserved time effects:

$$
\varepsilon_{t, i}=\mu_{i}+\lambda_{t}+v_{t, i}
$$

The two-way error component model assumes that the sum of the individual specific effects and the time specific effects to be zero $\left(\sum_{i=1}^{n} \mu_{i}=\sum_{t=1}^{T} \lambda_{t}=0\right)$.

\subsubsection{Two-Way Error Component Model}

$$
P R I C E_{t, i}=\beta_{0}+\beta_{1} E Q U I T Y_{t, i}+\beta_{2} E P S_{t, i}+\beta_{3} C E_{t, i}+Z_{\mu} \mu_{i}+Z_{\lambda} \lambda_{t}+v_{t, i}
$$

where:

- $Z_{\mu}$-matrix of the companies dummy; and

- $Z_{\lambda}$-matrix of the time dummy.

Since we believe that differences across companies could have some influence on the share price, a random effects model could be more appropriate. In order to produce reliable results, it is important that the unobserved variables to be uncorrelated with all the explanatory variables. The random effects approach will not remove the independent variables that do not vary over time and, hence, their impact can be enumerated. In the random effects model, the $\mu_{i}$ is part of the error term.

\subsubsection{Random Effects Model}

$$
\text { PRICE } E_{t, i}=\beta_{0}+\beta_{1} \text { EQUITY }_{t, i}+\beta_{2} \text { EPS }_{t, i}+\beta_{3} C E_{t, i}+\mu_{i}+v_{t, i}
$$




\subsection{Data Collection}

There are significant differences in the stock market valuation of accounting data. The application of the share price model on different capital markets revealed very different results, not only among the capital markets, but also among different industries [28]. In order to analyze the factors that affect the share price, these results require the necessity to apply the share price model for a specific capital market and industry. In order to test our hypotheses, we selected the London Stock Exchange (LSE), which is one of the oldest and largest stock exchanges in the world, with an age of 215 years, a market capitalization of $\$ 6187$ billion and 3041 quoted companies [29]. LSE comprises two markets: the Main Market (MM), dedicated to the largest companies, and the Alternative Investment Market (AIM), dedicated to the smaller companies from the UK and around the world [30].

The data were collected during June-September 2017 using the Thomson Reuters Eikon database for the period 2014-2016. We chose this period of time because during 2014-2016 the oil and gas prices had fallen [11] and OPEC countries allowed global well markets to operate without cartel interventions [31]. The price falling and the market liberalization represented the worst case scenario for financial performance of companies, more than $50 \%$ of the oil and gas companies listed on LSE have been recording losses during that period of time.

The value of equity, earnings and capital expenditure, at the balance sheet date, was extracted from the oil and gas companies' financial statements and the share price, at the balance sheet date, was extracted from the history price provided by the database. At that time, 114 oil and gas producers were listed on the LSE. Out of these, 35 companies are listed on the MM and 79 companies are listed on AIM. The companies with missing data regarding the price (18 companies), financial information (seven companies), and capital expenditure (nine companies) were eliminated. Since we need balanced data to test the share price model for fixed effects, we eliminated the companies which obtained profit in two years and loss in one year (10 companies) and the companies which obtained profit in one year and loss in two years (13 companies).

Since our goal was to establish how the investments in long-term assets, made by companies, influence the share price in profit companies (net income is profit for all analyzed period 2014-2016) opposed to loss companies (net income is loss for all analyzed period 2014-2016), we divided the data into two samples: one for profit companies and the other one for loss companies. This partition is in accordance with the results of other studies regarding the existence of a non-homogeneous relation between price and earnings across profit companies and loss companies with significant differences on earnings and book value coefficients [32].

For the analyzed companies, only 13 of them obtained profit in all three years, while 44 companies obtained losses in all three years. By testing the data for outliers, it resulted a number of two outliers for profit companies and four outliers for loss companies which were eliminated from the panel balanced data. Taking into consideration that the internal aspects of the companies or the time variables could affect our results, we tested the share price model for fixed and random effects using the balanced data for 11 profit companies and 40 loss companies. Table 1 presents the number of companies used for testing our hypotheses before and after the removals of companies due to the unknown data, unbalanced data, and outliers.

Table 1. Data selection.

\begin{tabular}{ccc}
\hline Specifications & MM & AIM \\
\hline Listed companies & 35 & 79 \\
\hline (-) Companies without share price information & $(6)$ & $(12)$ \\
$(-)$ Companies without financial information & $(1)$ & $(6)$ \\
$(-)$ Companies without capital expenditure in one or more years & $(0)$ & $(9)$ \\
\hline
\end{tabular}


Table 1. Cont.

\begin{tabular}{ccc}
\hline Specifications & MM & AIM \\
\hline All companies & 28 & 52 \\
\cline { 2 - 3 } & \multicolumn{2}{c}{80} \\
\hline (-) Companies that obtain profit in two years and loss in one year & $(10)$ \\
(-) Companies that obtain profit in one year and loss in two years & Profit companies & Loss companies \\
\hline Types of companies & 13 & 44 \\
Companies that obtain profit/loss in all three years & $(2)$ & $(4)$ \\
(-) Outliers & 11 & 40 \\
\hline
\end{tabular}

The profit and loss companies used in this study are presented in Appendix A, Table A1.

\section{Results and Discussion}

All of the companies from the energy market have raised their investments in new technologies and methods to be more efficient and to obtain performance. The acquisition of shares, as a practice, is made by investors. They are convinced to buy shares depending on their return, so the companies must show them how their initial investment in shares becomes profitable. To find all these actions made by companies, we were concerned with the usefulness and predictive value of their investments in long-term assets. The Ohlson price model used in this research derives from the residual income valuation model, which defines the share price as a sum of book value of equity and current earnings.

\subsection{Descriptive Statistics}

All the results disclosed in the paper were obtained by using the EViews 10 software (IHS Global Inc., Irvine, CA, USA). The descriptive statistics are presented in the Table 2, firstly for the profit companies and secondly for the loss companies.

Table 2. Descriptive statistics for the variables used in the price model.

\begin{tabular}{ccccccc}
\hline Types of Companies & Variables & Mean & StDev & Minimum & Median & Maximum \\
\hline \multirow{4}{*}{ Profit Companies } & PRICE & 35.6881 & 41.5848 & 0.6331 & 24.5000 & 150.0000 \\
& EQUITY & 3.4195 & 1.8523 & 0.1100 & 3.3360 & 7.7853 \\
& EPS & 0.4118 & 0.2730 & 0.0037 & 0.3670 & 1.1595 \\
& CE & 0.5695 & 0.4664 & 0.0346 & 0.3863 & 1.4072 \\
\hline \multirow{5}{*}{ Loss Companies } & PRICE & 37.1270 & 83.9948 & 0.1450 & 9.1375 & 700.0000 \\
& EQUITY & 0.6371 & 1.4581 & -0.1491 & 0.1638 & 11.0690 \\
& EPS & -0.2587 & 0.6914 & -4.0559 & -0.0313 & -0.00003 \\
& CE & 0.1064 & 0.2897 & 0.0001 & 0.0078 & 1.8748 \\
\hline
\end{tabular}

PRICE: market value of equity per share at the end of the year; EQUITY: book value of equity per share at the end of the year; EPS: earnings per share for the year; CE: capital expenditure per share for the year.

The mean of the share price for oil and gas companies, in the year when they obtained profit, is $€ 35.6881$, more than the median value, which is $€ 24.5$. The standard deviation is greater than the mean and has a value of $€ 41.5848$. The minimum value of the share price for profit companies is $€ 0.6331$, while the maximum value of $€ 150$ is large. This is normal taking into consideration that the companies listed on the MM and AIM are included in the sample. Standard deviation of the book value per share is less than the mean and the median value is very close to the mean. The minimum and maximum of the book value per share are lower than those of the share price, which means that some of the oil and gas companies have a very good reputation and potential for very large development. The amount of investments in long-term assets made by the profit companies is greater than the profit obtained by 
these companies. Thus, the mean and median of capital expenditure per share is greater than the mean and median of earnings per share. The standard deviation, for both capital expenditure and earnings per share are close to the mean. This signifies that many of the profit companies obtain comparable earnings. They invest in long-term assets more than the profit obtained.

The mean of the share price for oil and gas companies, in the year when they obtained losses, is $€ 37.127$, which is more than fifty times the book value per share. This signifies that, even in bad times, the oil and gas companies are stable and attract investors. The large range between the maximum value of share price, which is $€ 700$, and the minimum value, which is $€ 0.145$, explains the value of standard deviation. This is twice more than the mean. The median of the book value per share for loss companies is lower than that for profit companies due to the accumulated losses. The median of earnings per share is small. This means that many of the analyzed companies record small losses. It is very interesting that, even if the companies record losses, they invest a great deal in long-term assets. The median of the investments in long-term assets made by the companies that record losses is $€ 0.0078$, which is around 5\% of the book value of equity. However, the amount of the investments made by loss companies is smaller than the amount of the investments made by profit companies.

\subsection{Correlation Analysis}

Table 3 presents the Pearson bivariate correlation coefficients for profit and loss companies.

Table 3. Pearson correlation coefficients.

\begin{tabular}{cccccc}
\hline Types of Companies & Variables & PRICE & EQUITY & EPS & CE \\
\hline & PRICE & 1.00 & - & - & - \\
\multirow{2}{*}{ Profit Companies } & EQUITY & 0.34 & 1.00 & - & - \\
& EPS & $0.45^{* *}$ & $0.89^{* * *}$ & 1.00 & - \\
& CE & 0.00 & $0.71^{* * *}$ & $0.66^{* * *}$ & 1.00 \\
\hline
\end{tabular}

PRICE: logarithm of the market value of equity per share at the end of the year; EQUITY: logarithm of the book value of equity per share at the end of the year; EPS: logarithm of the earnings per share for the year; CE: logarithm of the capital

\begin{tabular}{cccccc}
\multicolumn{7}{c}{} \\
\hline \multirow{4}{*}{ Loss Companies } & PRICE & 1.00 & - & - & - \\
& EQUITY & $0.57^{* * *}$ & 1.00 & - & - \\
& EPS & $-0.34^{* * *}$ & $-0.53^{* * *}$ & 1.00 & - \\
& CE & $0.50^{* * *}$ & $0.30^{* * *}$ & -0.34 & 1.00
\end{tabular}

PRICE: logarithm of the market value of equity per share at the end of the year; EQUITY: book value of equity per share at the end of the year; EPS: earnings per share for the year; CE: capital expenditure per share for the year.

${ }^{* *},{ }^{* * *}$ statistically significant at $5 \%, 1 \%$, and $0.1 \%$ level.

These results highlight, for the profit companies, the moderate positive correlation of equity with earnings and capital expenditure, and between earnings and capital expenditure. In addition, there is a weak positive correlation of price with equity and earnings. It is important to notice the scant correlation that exists between price and capital expenditure.

For the loss companies, there is a weak positive correlation of price with equity and capital expenditure. Since these companies obtained losses, the correlation of price, equity, and capital expenditure with earning is negative, but also weak. The correlation between capital expenditure and equity is positive and negligible, and the correlation between earnings and capital expenditure is negative and negligible. 


\subsection{Data Testing}

A couple of tests were conducted in order to test the four assumptions of the OLS multiple regression model as, linear relationship, multivariate normality, no multicollinearity, and homoscedasticity. The results of these tests are presented in Table 4.

In order to assure a linear relationship between the dependent and independent variables we eliminated the outliers from our data. The outliers were identified to be the items with a $Z$ score less than -2.68 or greater than 2.68. The strength of the relationship between the OLS model and the response variable is estimated at $35.44 \%$ for the profit companies and $44.11 \%$ for the loss companies, the relationship being statistically significant at the $1 \%$ level for profit companies and at the $0.1 \%$ level for loss companies.

The multivariate normality was checked by using Jarque-Bera test. The results revealed that the share price for all companies and the capital expenditure for loss companies are normally distributed. Taking into consideration the fact that to draw a valid conclusion by hypothesis testing it is important in a multiple regression that the residuals be normally distributed, this assumption was validated by the Jarque-Bera test for both profit and loss companies.

The Pearson correlation matrix disclosed in the Table 3 shows that the correlation coefficients between independent variables are significantly different from zero at the $0.1 \%$ level. To test if multicollinearity could be spuriously responsible for our evidence on the predictions in the OLS regression, we calculated the variance inflation factor (VIF). The results reveal that the multicollinearity is not present in the OLS regression for loss companies, but it is present in the OLS regression for profit companies.

Table 4. Results of OLS regression testing.

\begin{tabular}{|c|c|c|c|}
\hline \multicolumn{2}{|c|}{ Tests } & \multirow{3}{*}{$\begin{array}{c}\text { Profit Companies } \\
35.44 \% \\
5.307 \\
\end{array}$} & \multirow{3}{*}{$\begin{array}{c}\text { Loss Companies } \\
44.11 \% \\
30.525\end{array}$} \\
\hline & $R$ square & & \\
\hline Linear Relationship & $F$ statistic & & \\
\hline \multirow{5}{*}{$\begin{array}{c}\text { Multivariate Normality- } \\
\text { Jarque-Bera Test }\end{array}$} & Residuals & 0.340 & 2.220 \\
\hline & PRICE & 0.563 & 1.237 \\
\hline & EQUITY & 4086 & 36.272 \\
\hline & EPS & 1799 & 28.618 \\
\hline & CE & 2414 & 2.639 \\
\hline \multirow{3}{*}{ No Multicollinearity-VIF } & EQUITY & 20.44 & 4.35 \\
\hline & EPS & 18.05 & 4.50 \\
\hline & $\mathrm{CE}$ & 7.28 & 3.57 \\
\hline \multirow{2}{*}{ Homoscedasticity } & Breusch-Pagan-Godfrey test & 1.304 & 1.207 \\
\hline & White test & 0.343 & 0.186 \\
\hline
\end{tabular}

Since the standard error is central to conducting significance tests and calculating confidence intervals, we conducted Breusch-Pagan-Godfrey and White tests for heteroscedasticity. Both tests reveal that heteroscedasticity is not present in the OLS models for both profit and loss companies.

The tests applied to check the assumptions of multiple linear regression were validated for all four necessary assumptions for loss companies, on the one hand, and for three of four necessary assumptions for profit companies, on the other hand (the multicollinearity is present in the sample of profit companies).

Five tests were conducted in order to choose the best model that explains the dependent variable. The results of these tests are presented in Table 5. 
Table 5. The models' quality.

\begin{tabular}{ccccc}
\hline Tests & Profit Companies & \multicolumn{2}{c}{ Loss Companies } \\
\hline \multirow{4}{*}{ Akaike Test } & 1. Two-way error component & -1.078 & 1. Two-way error component & 0.819 \\
& 2. FE/ Random cross sectional & -0.893 & 2. FE/ Random cross sectional & 1.025 \\
& 3. OLS regression & 1.678 & 3. FE time & 1.743 \\
& 4. FE time & 1.787 & 4. OLS regression & 1.747 \\
\hline \multirow{5}{*}{ Schwartz Test } & 1. Two-way error component & -0.352 & 1. OLS regression & 1.840 \\
& 2. FE/Random cross sectional & -0.258 & 2. Two-way error component & 1.864 \\
& 3. OLS regression & 1.859 & 3. FE time & 1.882 \\
& 4. FE time & 2.059 & 4. FE/Random cross sectional & 2.024 \\
\hline \multirow{3}{*}{ Hannan-Quinn Test } & 1. Two-way error component & -0.834 & 1. Two-way error component & 1.243 \\
& 2. FE/Random cross-sectional & -0.679 & 2. FE/Random cross-sectional & 1.431 \\
& 3. OLS regression & 1.739 & 3. OLS regression & 1.784 \\
& 4. FE time & 1.879 & 4. FE time & 1.799 \\
\hline \multirow{5}{*}{ Durbin-Watson Test } & 1. Two-way error component & 1.998 & 1. Two-way error component & 2.035 \\
& 2. FE cross-sectional & 2.353 & 2. FE cross-sectional & 2.120 \\
& 3. Random cross-sectional & 1.478 & 3. Random cross-sectional & 1.455 \\
& 4. OLS regression & 0.304 & 4. OLS regression & 0.565 \\
& 5. FE time & 0.264 & 5. FE time & 0.486 \\
\hline \multirow{2}{*}{ Hausman Test } & Chi-square statistic & 4.314 & Chi-square statistic & 1.706 \\
& Probability & 0.229 & Probability & 0.635 \\
\hline
\end{tabular}

The Akaike test reveals substantial evidence for the model quality regarding the OLS, fixed, and random effects models. Using the Akaike test, the two-way error component model is the most reliable.

The Schwartz test, as an increasing function of the residual sum of squares and of the number of free parameters to be estimated, penalizes the free parameters more strongly than does the Akaike test. In the case of profit companies, the results of the test show that the two-way error component model, as well as the company fixed effect or random model are preferred. In the case of loss companies, the preferred model is OLS, but also the two-way error component model or the time fixed effect produce almost the same fit. Similar to Schwartz test, the Hannan-Quinn test is strongly consistent and asymptotically very well-behaved, reflecting the true order of the models when the number of observations is large.

The Durbin-Watson test was conducted in order to check the autocorrelation of the errors. Since, in the OLS model, the test value is substantially less than 1.258 for profit companies and 1.645 (value obtained by interpolation) for loss companies, there is evidence of positive serial correlation. This is normal, taking into consideration that the data were collected using the same source. The alternative models used in the paper, in order to eliminate the autocorrelation of the errors, pass this test only in the case of the two-way error component model, for both profit and loss companies. The results of the Durbin-Watson test reveal the presence of a serial negative autocorrelation for the company fixed effect model, on the one hand, and the presence of a serial positive autocorrelation for the random model, on the other hand. In the case of the time fixed effects model, the very low value of the Durbin-Watson test defines the cause for concern about the reliability of the model estimates, so we could not rely our conclusions on this model.

An important assumption of the company fixed effect model is that the time-invariant characteristics of each company must be unique and not correlated with the other companies' characteristics. If there is a correlation between the unique errors and the explanatory variables, then the company fixed effect model does not provide correct estimates and we need to model the relationship by using the random effect model. The Hausman test has the capacity to provide evidence to choose between a company fixed effects model or a random effects model. In our case, the Hausman test reveals that the random effects model should be used for both profit and loss companies.

For a small number of observations, as in the case of profit companies, Akaike test is more consistent and reflects more accurately the true order of the models than the Schwartz and 
Hannan-Quinn tests do. The two-way error component model seems to be the best model to predict the estimators for profit companies. For a number of 120 observations, as in the case of the loss companies, following Asghar and Abid's recommendations [33], the Schwartz test reflects more accurately the true order of the models, meaning that the OLS is the best model to predict the estimators for loss companies. In analyzing our results, we will take also into consideration the results of the two-way error component model based on the following reasons: it is validated to be the best model by the other two tests; it has a Schwartz value very close to the OLS model, and it is the only model with no autocorrelation of the errors.

\subsection{Results}

The study results could be sustained by the confidence of investors in the international bodies' strategies regarding long-term commitment to make their energy systems climate-neutral [34]. Given this, our article draws original empirical insights from the oil and gas industry, where the share price is explained by the companies' investment in long-term assets, instead of financial performance. Maybe the investors are conscientious about the real perspective of the domain transformation through a sustainable one. The investments in long-term assets, from the investors' perspective, could be the way to solve the energy trilemma-the competing goals of energy security, environmental sustainability, and energy equity [35].

Estimating the extended share price model by OLS, company fixed effects, time fixed effects, two-way error component, and random effects models for the two samples (profit and loss companies) we present, in Tables 6 and 7, the slope coefficients, the related $t$-statistics (in parentheses), the $R$ square, and F statistic of each model. According to the F statistic, all the models are highly significant (except for the random model in the case of profit companies). Since the number of companies which recorded losses is greater than the number of companies which recorded profit, the share price model produces better results for loss companies due to the large size of the sample.

Table 6. Coefficients analysis for profit companies.

\begin{tabular}{cccccc}
\hline Models & $\begin{array}{c}\text { OLS } \\
\text { Regression }\end{array}$ & $\begin{array}{c}\text { Company } \\
\text { Fixed Effects }\end{array}$ & $\begin{array}{c}\text { Time Fixed } \\
\text { Effects }\end{array}$ & $\begin{array}{c}\text { Two-Way Error } \\
\text { Component }\end{array}$ & $\begin{array}{c}\text { Random } \\
\text { Effects }\end{array}$ \\
\hline Specifications & Equation (1) & Equation (3) & Equation (5) & Equation (7) & Equation (8) \\
\hline \multirow{2}{*}{ Intercept } & $1.397^{* *}$ & $1.090^{* * *}$ & $1.373^{* *}$ & $0.961 * *$ & $1.075^{* * *}$ \\
\cline { 2 - 6 } & $(3.228)$ & $(5.750)$ & $(2.925)$ & $(3.711)$ & $(4.427)$ \\
\hline \multirow{2}{*}{ EQUITY } & 0.013 & 0.339 & 0.041 & 0.628 & 0.368 \\
& $(0.027)$ & $(0.950)$ & $(0.077)$ & $(1.310)$ & $(1.334)$ \\
\hline \multirow{2}{*}{ EPS } & $0.842^{*}$ & 0.091 & $0.830 *$ & 0.085 & 0.122 \\
& $(2.349)$ & $(0.683)$ & $(2.194)$ & $(0.672)$ & $(0.944)$ \\
\hline \multirow{2}{*}{ CE } & $-0.651^{*}$ & -0.079 & $-0.661 *$ & -0.098 & -0.124 \\
\hline$R$ Square & $(-2.474)$ & $(-0.474)$ & $(-2.372)$ & $(-0.588)$ & $(-0.826)$ \\
\hline F statistic & $35.44^{*} \%$ & $97.30 \%$ & $36.21 \%$ & $98.01 \%$ & $13.07 \%$ \\
\hline
\end{tabular}

PRICE: logarithm of the market value of equity per share at the end of the year; EQUITY: logarithm of the book value of equity per share at the end of the year; EPS: logarithm of the earnings per share for the year; CE: logarithm of the capital expenditure per share for the year.

$*, * *, * * *$ statistically significant at the $5 \%, 1 \%$, and $0.1 \%$ level. 
Table 7. Coefficients analysis for loss companies.

\begin{tabular}{cccccc}
\hline Models & $\begin{array}{c}\text { OLS } \\
\text { Regression }\end{array}$ & $\begin{array}{c}\text { Company } \\
\text { Fixed Effects }\end{array}$ & $\begin{array}{c}\text { Time Fixed } \\
\text { Effects }\end{array}$ & $\begin{array}{c}\text { Two-Way Error } \\
\text { Component }\end{array}$ & $\begin{array}{c}\text { Random } \\
\text { Effects }\end{array}$ \\
\hline Specifications & Equation (1) & Equation (3) & Equation (5) & Equation (7) & Equation (8) \\
\hline \multirow{2}{*}{ Intercept } & $0.716^{* * *}$ & $0.803^{* * *}$ & $0.722^{* * *}$ & $0.867^{* * *}$ & $\begin{array}{c}0.741^{* * *} \\
(1250)\end{array}$ \\
& $(12.228)$ & $(11.054)$ & $(12.439)$ & $(12.899)$ & $0.550)$ \\
\hline \multirow{2}{*}{ EQUITY } & $0.246^{* * *}$ & 0.147 & $0.241^{* * *}$ & 0.084 & $0.225^{* * *}$ \\
& $(5.809)$ & $(1.580)$ & $(5.731)$ & $(0.991)$ & $(4.842)$ \\
\hline \multirow{2}{*}{ EPS } & 0.042 & 0.099 & 0.034 & 0.102 & 0.037 \\
& $(0.470)$ & $(0.835)$ & $(0.379)$ & $(0.952)$ & $(0.475)$ \\
\hline \multirow{2}{*}{ CE } & $0.950^{* * *}$ & $0.863^{* *}$ & $0.896^{* * *}$ & $0.638^{*}$ & $0.826^{* * *}$ \\
& $(4.912)$ & $(2.807)$ & $(4.624)$ & $(2.270)$ & $(3.973)$ \\
\hline$R$ Square & $44.11^{* *}$ & $85.81^{*} \%$ & $46.16^{*} \%$ & $88.84^{*} \%$ & $33.22 \%$ \\
\hline F statistic & $30.525^{* * *}$ & $11.09^{* * *}$ & $19.550^{* * *}$ & $13.574^{* * *}$ & $19.237^{* * *}$ \\
\hline
\end{tabular}

PRICE: logarithm of the market value of equity per share at the end of the year; EQUITY: book value of equity per share at the end of the year; EPS: earnings per share for the year; CE: capital expenditure per share for the year.

$*, * *, * * *$ statistically significant at the $5 \%, 1 \%$, and $0.1 \%$ level.

Comparing the five models presented above for profit companies, the explanatory variable of capital expenditure seems to be significant at the $5 \%$ level in the case of OLS and time fixed effects model. However, as our tests prove, the multicollinearity assumption was broken in the case of the OLS model and the autocorrelation assumption was broken in the case of the time fixed effects model. Therefore, we could not base our arguments on these two models because the coefficient estimates are biased. Additionally, the random effect model is not significant enough to provide statistically significant results. The Hausman test proves that the estimates based on the company fixed effect model are not consistent, so we did not base our arguments on this model. Consequently, for profit companies, we tested the first hypothesis on the results of the two-way error component model which gives the most accurate results. For this model, in the case of profit companies, the adjusted $\mathrm{R}$ square is $98.01 \%$. The coefficients for equity and earnings are positive and insignificant at the $5 \%$ level. The coefficient for capital expenditure is negative, but not significant at the $5 \%$ level, thus, we could not conclude that the share price is influenced by the amount of investment in long-term assets made by profit companies. In this case we invalidate the first hypothesis that the investments in long-term assets made by profit companies influence the share price.

Comparing the five models presented above for the loss companies, the explanatory variable of capital expenditure is significant at the 5\% level in all the cases. Since the Durbin-Watson test proves that the autocorrelation assumption was broken in the case of time fixed effects model and the Hausman test proves that the correlation exists between the individual error and the explanatory variables in the case of the company fixed effect model, we did not base our arguments on these models. Consequently, for the loss companies, we tested the second hypothesis using the OLS model results (considered our tests to be the most accurate) and, also, on the random and the two-way error component models. The random effects model produces very similar results with those of the OLS model.

Based on the OLS model, the explanatory variables explain about $44.11 \%$ of the share price in the case of loss companies (33.22\% in the case of random effects model). Taking into consideration the individual companies effects and time effects, the two-way error component model explains about $88.84 \%$ of the share price. For all data, the coefficient for earnings is not significant at the $5 \%$ level. In contrast, the coefficients for equity and capital expenditure are positive and significant at the $0.1 \%$ level in the OLS and random effects models. However, taking into consideration the 
individual company effects and time effects, in the two-way error component model, only the capital expenditure is significant at the $5 \%$ level. In this case, one unit of investment amount per share made by loss companies increases in average with $0.638 \%$ the share price, which is a good sign for investors. In conclusion, based on the OLS model, random effects model, and the two-way error component model, we validate the second hypothesis that the investments in long-term assets made by loss companies influence the share price.

It is important to notice the low magnitudes of earnings response coefficients for both profit and loss companies. Some arguments could explain these low values of earnings coefficients [36]: prices lead earnings (validated for our sample only for loss companies); noise in earnings (which exist only in the years when companies obtain profit); or inefficient capital markets (which is not the case of LSE) in accordance with Rounaghi and Zadeh (2016) [37]. When a company records losses, Boyer and Filion (2007) [38] found, in the case of oil and gas companies listed on Canadian Stock Exchange, that the equity has high information content, either as a proxy for prospective earnings or as a proxy for abandonment/adaptation value, but this statement was not validated for oil and gas companies listed on the LSE.

The results of our study reveal very different behavior of investors on the companies that record profit in comparison with the companies that record losses. It is very well known that investments made by companies influence the performance of the company. In this context, it is expected that investors may decide to buy shares at companies that make investments in long-term assets (they follow to obtain profit). However, the results of our study show that investors are positively influenced in the decision-making process by the investments in long-term assets made only by the companies that record losses, but not profit. These results are very important taking into consideration that many companies decide to decrease investments in long-term assets in the years when they obtain losses.

\section{Conclusions}

Through this research the solidity and reliability of oil and gas shares due to investments in long-term assets in the case of companies that record losses was proved. The share price model is a proving ground for investments and it was found that, through investments, the companies could attain the real performance, going from losses to profit in the future. Somewhat, this could be an explanation for investors who are interested in additional information that explains how the companies could obtain performance.

The results of this study confirm the existence of the internal mechanisms of the companies to attract investors. Analytical results showed that capital expenditure positively influence the share price. Investing in long-term assets, in times when companies obtain losses, neutralizes the negative perception that losses could generate. The investors associate the investments in long-term assets, in these difficult financial periods, with the implementation of concrete actions for the future development of the company in order to cover losses and generate profit.

The results confirm the relevance of financial information in influencing the investors' behavior on the capital market during the period of falling crude oil prices and the transition to the use of renewable energy. Through statistical tests on the panel data, it was proved that capital expenditure, as the independent variable, is the most powerful explicative variable among the book value of equity and earnings per share. Choosing the panel data, we faced the challenge of panel methodology and had to control for the impact of unobserved heterogeneity, represented by the incidental parameters. The decision to choose between our proposed and discussed models brought to attention advantages and disadvantages of these and offered consistency of our research. Since our samples had a population split between profit and loss companies, practically it reduced the number of sample observations. This represents a weak point of our research, because through this decision we accepted that unknown parameters decreased with the number of sample observations.

The results are important for managers of energy companies who should increase the investments in long-term assets during difficult financial periods, and also for the governments which could 
promote encouraging investments policies for these companies. In this way, the states or regional institutions could accomplish their social issues regarding employability, poverty reduction, and could make the economic environment friendly for other industries or businesses. Developing literature and offering a solution for environmental protection are, at the same time, good lessons for policy-makers.

Grounded on an interdisciplinary approach, bringing together accounting information, investments domain, and companies' care for the environment, our results integrate this research within the energy justice concept, especially the aspect of the external aims beyond academia [39]. This research could represent a part of the literature used for debate in energy and sustainability issues. The interdisciplinary character of energy offers a real perspective for academics to improve the domain knowledge and to promote the strategies, which could make the world a better place. Energy, as a research topic, is suitable for university curricula. Additionally, the aspect of investments' benefits in long-term assets is a way to reduce the environmental impact of the oil and gas industry's activities. The world economies are going to decarbonize energy resources. Oil and gas energy companies are in a transition to environmentally friendly ones. Related to this aspect, it is important to highlight the political and socio-technical matter, which is brought to attention by the investments issue, as a very interesting topic for future studies. It this way, the companies must extend their investments in long-term assets and the social and environmental aspects must become the expression of the conscientious company's behavior.

This paper is the first to study the usefulness of investments of loss-making companies in the oil and gas industries, using the share price model. These results should be viewed as a topic of future developments.

Acknowledgments: The authors would sincerely like to thank the anonymous peer reviewers for their helpful comments and suggestions. Thanks for Ionela Guşatu (Department of Modern Languages, "Carol Davila" University of Medicine and Pharmacy, Bucharest, Romania) who checked the English for the later version of our manuscript.

Author Contributions: The authors of this article have equally contributed to every stage in its development.

Conflicts of Interest: The authors declare no conflict of interest.

\section{Appendix A}

Table A1. Profit and loss oil and gas companies.

\begin{tabular}{clcl}
\hline No. & \multicolumn{1}{c}{ Profit Companies } & No. & \multicolumn{1}{c}{ Loss Companies } \\
\hline 1 & ELAND OIL \& GAS & 1 & 88 ENERGY \\
2 & EMPYREAN ENERGY & 2 & AMINEX \\
3 & EXILLON ENERGY & 3 & ASCENT RESOURCES \\
4 & GAIL (INDIA) & 4 & BAHAMAS PETROLEUM COMPANY \\
5 & GAZPROM NEFT PJSC & 5 & BARON OIL \\
6 & PAO NOVATEK & 6 & BORDERS \& SOUTHERN PETROLEUM \\
7 & PJSC GAZPROM & 7 & BOWLEVEN \\
8 & PJSC TATNEFT & 8 & CADOGAN PETROLEUM \\
9 & RELIANCE INDUSTRIES & 9 & CAIRN ENERGY \\
10 & ROSNEFT OIL COMPANY & 10 & CANADIAN OVERSEAS PETROLEUM \\
11 & SOCIETATEA NAT.DE GAZE NAT.ROMGAZ & 11 & CHARIOT OIL \& GAS \\
& & 12 & COLUMBUS ENERGY RESOURCES \\
& & 13 & ECHO ENERGY \\
& & 14 & FALCON OIL \& GAS \\
& & 15 & FAROE PETROLEUM \\
& & 16 & GENEL ENERGY \\
& & 17 & GLOBAL PETROLEUM \\
& & 18 & HARDY OIL \& GAS \\
& & 20 & JKX OIL \& GAS \\
& & 21 & MAYAN LIMITED ENERGY LIMITED \\
\hline
\end{tabular}


Table A1. Cont.

\begin{tabular}{lcl}
\hline No. & No. & \multicolumn{1}{c}{ Loss Companies } \\
\hline & 23 & NIGHTHAWK ENERGY \\
& 24 & NOSTRA TERRA OIL\&GAS COMPANY \\
25 & OILEX & \\
& 26 & PANTHEON RESOURCES \\
& 27 & PETREL RESOURCES \\
& 28 & PHOENIX GLOBAL RESOURCES \\
& 29 & QUADRISE FUELS INTERNATIONAL \\
& 30 & RED EMPEROR RESOURCES \\
& 31 & ROSE PETROLEUM \\
& 32 & SAVANNAH PETROLEUM \\
& 33 & SOLO OIL \\
& 34 & SOUND ENERGY \\
35 & SPITFIRE OIL \\
& 36 & STERLING ENERGY \\
37 & TOMCO ENERGY \\
38 & TOWER RESOURCES \\
39 & TULLOW OIL \\
40 & UNION JACK OIL \\
\hline &
\end{tabular}

\section{References}

1. Roychaudhuri, P.S.; Kazantzi, V.; Foo, D.C.Y.; Tan, R.R.; Bandyopadhyay, S. Selection of energy conservation projects through Financial Pinch Analysis. Energy 2017, 138, 602-615. [CrossRef]

2. Krupa, J.; Harvey, L.D.D. Renewable electricity finance in the United States: A state-of-the-art review. Energy 2017, 135, 913-929. [CrossRef]

3. Healy, N.; Barry, J. Politicizing energy justice and energy system transitions: Fossil fuel divestment and a "just transition". Energy Policy 2017, 108, 451-459. [CrossRef]

4. Discarding, G.; Morrison, R.; Branson, D.; Maestro, A. 2017 Oil and Gas Trends. Available online: https:/ / www. strategyand.pwc.com/trend/2017-oil-and-gas-trends (accessed on 7 September 2017).

5. Freeman, R.E. Strategic Management: A Stakeholder Approach; Pitman Press: Boston, MA, USA, 1984.

6. Weijermars, R. Accelerating the three dimensions of E\&P clockspeed-A novel strategy for optimizing utility in the Oil\&Gas industry. Appl. Energy 2009, 86, 2222-2243.

7. Chen, Y.; Feng, L.; Wang, J.; Hook, M. Emergy-based energy return on investment method for evaluating energy exploitation. Energy 2017, 128, 540-549. [CrossRef]

8. Kishimoto, J.; Goto, M.; Inoue, K. Do acquisitions by electric utility companies create value? Evidence from deregulated markets. Energy Policy 2017, 105, 212-224. [CrossRef]

9. Hoeven, M. IEA vision on international energy governance. Energy Strategy Rev. 2012, 1, 73-75. [CrossRef]

10. Jano-Ito, M.A.; Crawford-Brown, D. Investment decisions considering economic, environmental and social factors: An actors' perspective for the electricity sector of Mexico. Energy 2017, 121, 92-106. [CrossRef]

11. Statista. Average Annual OPEC Crude Oil Price from 1960 to 2017 (in U.S. Dollars per Barrel). Available online: https:/ / www.statista.com/statistics/262858/change-in-opec-crude-oil-prices-since-1960/ (accessed on 20 November 2017).

12. Gleadle, P.; Haslam, C. An exploratory study of an early stage R\&D-intensive firm under financialization. Account. Forum 2010, 34, 54-65.

13. Andersson, T.; Haslam, C.; Lee, E.; Tsitsianis, N. Financialization directing strategy. Account. Forum 2008, 32, 261-275. [CrossRef]

14. Zhou, X.; Reesor, R.M. Misrepresentation and capital structure: Quantifying the impact on corporate debt value. J. Corp. Financ. 2015, 34, 293-310. [CrossRef]

15. Blacconiere, W.G.; DeFond, M.L. An investigation of independent audit opinions and subsequent independent auditor litigation of publicly-traded failed savings and loans. J. Account. Public Policy 1997, 16, 415-454. [CrossRef]

16. Orlitzky, M.; Schmidt, F.L.; Rynes, S.L. Corporate social and financial performance: A meta-analysis. Org. Stud. 2003, 24, 403-441. [CrossRef] 
17. Beurden, P.; Gössling, T. The worth of values-A literature review on the relation between corporate social and financial performance. J. Bus. Ethics 2008, 82, 407-424. [CrossRef]

18. Elyasiania, E.; Mansur, I.; Odusami, B. Oil price shocks and industry stock returns. Energy Econ. 2011, 33, 966-974. [CrossRef]

19. Grullon, G.; Lyandres, E.; Zhda, A. Real Options, Volatility, and Stock Returns. Available online: http:/ / citeseerx.ist.psu.edu/viewdoc/download?doi=10.1.1.225.4222\&rep=rep1\&type=pdf (accessed on 22 November 2017).

20. Schaeffer, R.; Borba, B.S.M.C.; Rathmann, R.; Szklo, A.; Branco, D.A.C. Dow Jones sustainability index transmission to oil stock market returns: A GARCH approach. Energy 2012, 45, 933-943. [CrossRef]

21. Ohlson, J.A. Earnings, book values, and dividends in security valuation. Contemp. Account. Res. 1995, 11, 161-182. [CrossRef]

22. Wafi, A.S.; Hassan, H.; Mabrouk, A. Fundamental Analysis Models in Financial Markets-Review Study. Procedia Econ. Financ. 2015, 30, 939-947. [CrossRef]

23. Holthausen, R.W.; Watts, R.L. The relevance of the value-relevance literature for financial accounting standard setting. J. Account. Econ. 2001, 31, 3-75. [CrossRef]

24. Collins, D.; Maydew, E.; Weiss, I. Changes in the value-relevance of earnings and book values over the past forty years. J. Account. Econ. 1997, 24, 39-67. [CrossRef]

25. Bao, B.H.; Chow, L. The usefulness of earnings and book value for equity valuation in emerging capital markets: Evidence from listed companies in the People's Republic of China. J. Int. Financ. Manag. Account. 1999, 10, 85-104. [CrossRef]

26. Jianu, I.; Jianu, I.; Turlea, C. Measuring the company's real performance by physical capital maintenance. Econ. Comput. Econ. Cybern. Stud. Res. 2017, 51, 37-57.

27. Jianu, I.; Jianu, I.; Ileanu, B.V.; Nedelcu, M.V.; Herteliu, C. The value relevance of financial reporting in Romania. Econ. Comput. Econ. Cybern. Stud. Res. 2014, 48, 167-182.

28. Ballas, A.A.; Hevas, D.L. Differences in the valuation of earnings and book value: Regulation effects or industry effects? Int. J. Account. 2005, 40, 363-389. [CrossRef]

29. Desjardins, J. Here Are the 20 Biggest Stock Exchanges in the World. Available online: http://uk. businessinsider.com/here-are-the-20-biggest-stock-exchanges-in-the-world-2017-4? $\mathrm{r}=\mathrm{US} \& \mathrm{IR}=\mathrm{T}$ (accessed on 23 November 2017).

30. Mansaku, I.; Mansaku, S.; Tampakoudis, I. An empirical comparison of the major stock exchanges: NYSE, NASDAQ and LSE in Perspective. Acad. J. Interdiscip. Stud. 2016, 5, 406-415. [CrossRef]

31. Wang, K.; Vredenburg, H.; Wang, J.; Xiong, Y.; Feng, L. Energy return on investment of Canadian oil sands extraction from 2009 to 2015. Energies 2017, 10, 614. [CrossRef]

32. Collins, D.W.; Pincus, M.; Xie, H. Equity valuation and negative earnings: The role of book value of equity. Account. Rev. 1999, 74, 29-61. [CrossRef]

33. Asghar, Z.; Abid, I. Performance of Lag Length Selection Criteria in Three Different Situations. Available online: https: / / mpra.ub.uni-muenchen.de/40042 (accessed on 15 November 2017).

34. Kaltenegger, O.; Löschel, A.; Baikowski, M.; Lingens, J. Energy costs in Germany and Europe: An assessment based on a (total real unit) energy cost accounting framework. Energy Policy 2017, 104, 419-430. [CrossRef]

35. Holley, C.; Lecavalier, E. Energy governance, energy security and environmental sustainability: A case study from Hong Kong. Energy Policy 2017, 108, 379-389. [CrossRef]

36. Kothari, S.P. Capital Markets Research in Accounting. J. Account. Econ. 2001, 31, 105-231. [CrossRef]

37. Rounaghi, M.M.; Zadeh, F.N. Investigation of market efficiency and Financial Stability between S\&P 500 and London Stock Exchange: Monthly and yearly Forecasting of Time Series Stock Returns using ARMA model. Physica A 2016, 456, 10-21.

38. Boyer, M.M.; Filion, D. Common and fundamental factors in stock returns of Canadian oil and gas companies. Energy Econ. 2007, 29, 428-453. [CrossRef]

39. Heffron, R.J.; McCauley, D. The concept of energy justice across the disciplines. Energy Policy 2017, 105, 658-667. [CrossRef]

(C) 2018 by the authors. Licensee MDPI, Basel, Switzerland. This article is an open access article distributed under the terms and conditions of the Creative Commons Attribution (CC BY) license (http://creativecommons.org/licenses/by/4.0/). 